\title{
Statyba
}

\section{NEW EQUATIONS FOR PREDICTING THE FROST RESISTANCE OF CERAMIC PRODUCTS BY DEFORMATIONAL PARAMETERS}

\section{A. Kičaitè \& R. Mačiulaitis}

To cite this article: A. Kičaitè \& R. Mačiulaitis (2001) NEW EQUATIONS FOR PREDICTING THE FROST RESISTANCE OF CERAMIC PRODUCTS BY DEFORMATIONAL PARAMETERS, Statyba, 7:2, 131-137, DOI: 10.1080/13921525.2001.10531714

To link to this article: https://doi.org/10.1080/13921525.2001.10531714

Published online: 30 Jul 2012.

Submit your article to this journal $\llbracket$

Џ Article views: 46 


\title{
NAUJOS KERAMINIŲ GAMINIŲ ATSPARUMO ŠALČIUI PROGNOZAVIMO LYGTYS NAUDOJANT DEFORMACINIUS RODIKLIUS
}

\author{
A. Kičaitè, R. Mačiulaitis \\ Vilniaus Gedimino technikos universitetas
}

\section{Ivadas}

Lietuvoje bei kitose Baltijos ir Šiaurès šalyse pastatų fasaduose dažnai galima matyti keraminiu apdailos plytų suirimų, kurie atsiranda dèl kritulių, šalčio ir šilumos poveikio [1].

Vienas iš svarbiausių rodiklių, charakterizuojančių keraminiu gaminių ilgalaikiškuma, yra ju atsparumas salčiui. Ši rodikli galima nustatyti tiesioginiais ir sparčiaisiais metodais.

Keraminių gaminių atsparumo šalčiui tyrimai tiesioginiais metodais užtrunka nuo kelių savaičių iki keliolikos mènesių. Greitai, per kelias ar keliolika parų, keraminių gaminių atsparumą šalčiui galima jvertinti tik sparčiaisiais prognozavimo metodais $[2,3]$.

Objektyviausiai prognozuoti keraminių gaminių atsparumą šalčiui galima tik kompleksiškai, ịvertinant daugeli gaminio savybių. Greitai prognozuoti keraminių gaminių atsparumą šalčiui galima pagal: 1) porų ir kapiliarų dydị bei jų kiekybini pasiskirstymą; 2) struktūrinius ir deformacinius rodiklius; 3) fizikines, mechanines ir struktūrines charakteristikas [4].

Tyrinètojai [5] parengè tūrini dilatometrini metodą keraminèms plytelèms tirti. Jie nustatè, kad geriau išdegtos plytelès mažiau deformuojàsi ir yra atsparesnès šalčiui. Tačiau toks metodas nebuvo pakankamai objektyvus ir perspektyvus, kadangi ir tiesioginiai kalibravimui atsparumo šalčiui rodikliai taip pat buvo nustatomi tūriniu šaldymo metodu. Tokiu atveju procesai, vykstantys keraminiame gaminyje, neatspindi procesu, vykstančiu gamini šaldant natūrinèmis eksploatacijos sąlygomis [1-3].

Pastaruoju metu tiek dilatometriniams, tiek tiesioginiams tyrimams vis plačiau taikomas vienpusis šaldymo principas. Vienas iš nauju dilatometrinių prietaisu, kuriuo galima nustatyti daugeli deformaciniu rodiklių šaldant iš vienos pusès, yra prietaisas DUM-01 [2, 3, 6]. Juo galima îvertinti gaminių vidinès struktūros pokyčius, kurie ir yra susije su itempimais ir deformacijomis, atsiradusiais bandinius šaldant bei atšildant iš vienos pusès. Tai leidžia gerokai tiksliau spręsti apie keraminių plytú eksploatacinị atsparumą šalčiui.

Todèl aktualu toliau tobulinti sparčiuosius prognozavimo metodus, remiantis keraminio gaminio deformaciniais ir struktūriniais rodikliais bei jų sąryšiu su atsparumu šalčiui, kuris nustatomas vienpusio šaldymo būdu, taip pat naujai pagrịsti tokių metodų deformacinius rodiklius.

\section{Tyrimo metodika ir aparatūra}

Kurdami naują spartuji eksploatacinio atsparumo šalčiui metodą ištyrème keturiu gamyklų 40 keraminių (paprastų ir apdailos) plytų, pagamintų pagal plastinio ir pussausio presavimo technologijas, bandinius. Plytos buvo pjaunamos pusiau ir atitinkamai naudojamos tiesioginiams atsparumo šalčiui bandymams bei ju deformaciju ir struktūros tyrimams.

Keraminiu plytų puselių imirkio rodiklis buvo nustatomas pagal LST 1272-92:1992 ( $W_{48}$ po $48 \mathrm{~h}$ ). Toliau iš anksto imirkytos pusplytès buvo tiriamos specialiu dilatometriniu prietaisu DUM-01 (1 pav.). Bandymo eiga buvo tokia: iš anksto įmirkytą bandinị (pusplytę) iš šonų fiksuojame šešiais srieginiais laikikliais pasirinktinai ta puse (galine ar šonine plokštuma) i viršut, kuri bus statinio fasade. Viršutinès bandinio plokštumos centre atremiamas deformaciju matavimo daviklis ir ant paviršiaus nuleidžiamas mikrošaldytuvas.

Tiriamojo sluoksnio storis yra $15 \mathrm{~mm}$ ir jis sutampa su plytos ištisiniu sluoksniu, nesiekiančiu technologinių tuštumų. Būtent tokiame sluoksnyje vyksta 

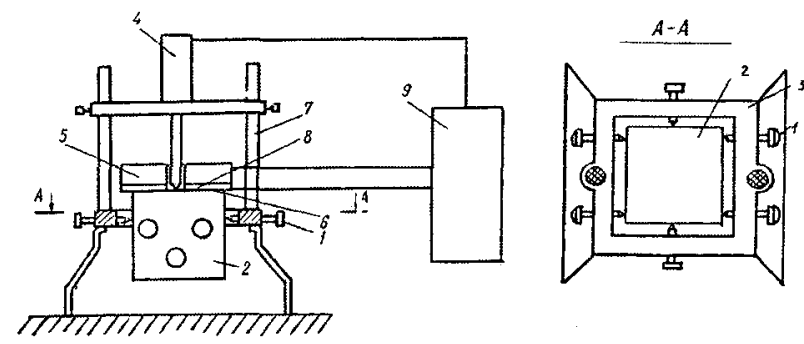

1 pav. Vienpusio šaldymo ir atšildymo dilatometrinio prietaiso DUM-01 schema: 1 - srieginiai laikikliai; 2 tiriamasis bandinys su šilumos izoliacija aplink; 3 pagrindas, 4 - deformacijos matavimo daviklis; 5 mikrošaldytuvas; 6 - temperatūros daviklis; 7 kreipiamosios; 8 - bandinio šaldomasis paviršius; 9 deformacijų matavimo ir užrašymo irenginys

Fig 1. The scheme of unilateral freezing/heating dilatometer DUM-01 unit: 1 - bolts; 2 - test specimen with thermal insulation around; 3 - base; 4 - deformation sensor, 5 - freezer unit; 6 - temperature sensor; 7 guides; 8 - freezing surface of the specimen; 9 - deformation measuring unit

plytu paviršiaus irimai pastatu fasaduose [2]. Šaldymo ir atšildymo ciklai buvo atliekami pagal specialų režimą ( 3 šaldymo ir atšildymo ciklai per $7-8 \mathrm{~h}$ ). Ju metu buvo matuojamas bandinio linijinis pailgèjimas ar susitraukimas (linijinè deformacija) šilumos srauto nutekèjimo ir pritekèjimo kryptimi. Savirašiu nuolat fiksuotas deformacijų kitimas laikui bėgant. Kadangi deformacijos kreivès buvo ivairaus pobūdžio, atskaitos tašku (nuliu) laikyta pradinè nusistovejusios kreives dalis (po 10$15 \mathrm{~min}$ ) prieš pradedant bandinio pirmaji šaldymą. Iš šiu kreiviu buvo skaičiuojami tokie absoliutieji deformaciniai rodikliai: $\Delta h_{1}-$ didžiausia bendra linijinè deformacija 1-ajame cikle šaldant, $\mu \mathrm{m} ; \Delta h_{2}$ - didžiausia bendra linijinè deformacija 2-ajame cikle šaldant, $\mu \mathrm{m}$; $\Delta h_{3}$ - didžiausia bendra linijinè deformacija 3-ajame cikle šaldant, $\mu \mathrm{m} ; \Delta h_{11}$ - didžiausia liekamoji deformacija 1-ajame cikle šildant, $\mu \mathrm{m} ; \Delta h_{21}$ - didžiausia liekamoji deformacija 2-ajame cikle šildant, $\mu \mathrm{m} ; \Delta h_{3 !}$ - didžiausia liekamoji deformacija 3-ajame cikle šildant, $\mu \mathrm{m}$.

Deformaciją (kreivès apibrěžtą plotą) išreiškus sąlyginiais ploto vienetais $\left(\mathrm{cm}^{2}\right)$ skiriami salyginiai deformaciniai rodikliai $s_{1}, s_{2}, s_{3}, s_{4}\left(s_{1}, s_{2}\right.$ yra 1-ojo ciklo rodikliai šaldant ir atšildant, $s_{3}, s_{4}$ - atitinkamai 2-ojo ciklo rodikliai šaldant ir atšildant). Nauji integraliniai deformaciniai rodikliai leidžia parodyti energetinị ardymo mechanizmo pobūdị.
Preliminarūs tyrimai parodè, jog buvo fiksuojamos deformacinių rodikliu teigiamos ir neigiamos reikšmės atskaitos taško atžvilgiu.

Tiesioginiai keraminių pusplyčiu atsparumo šalčiui bandymai buvo atliekami vienpusio šaldymo būdu pagal LST 1272-92:1992, p. 3.8.3. Vandenyje iš anksto imirkyti bandiniai mūro fragmente buvo $8 \mathrm{~h}$ šaldomi minus $(15-20){ }^{\circ} \mathrm{C}$ temperatūroje, tada $8 \mathrm{~h}$ atšildomi lietinant mūro fragmenta.

Tiesioginių bandymu metu buvo stebèta ir fiksuota keraminiu pusplyčiu šaldomojo paviršiaus suirimo dinamika. Suirimo pradžia laikytas ciklas, kai šaldomojo bandinio paviršiaus nuyra ne mažiau kaip 3\% (pagal LST 1413.12:1998), atsparumo šalčiui rodiklis $M_{1}$. Nuo pirmujų matomų suirimo požymių iki visiško paviršiaus suirimo praeina tam tikras laiko tarpas. Suirimo pabaiga laikytas ciklas, kai praktiškai suyra visas šaldomasis paviršius (atsparumo šalčiui rodiklis $M_{2}$ ).

\section{Tyrimo rezultatai ir jų aptarimas}

\subsection{Keraminio gaminio irimo proceso ypatumai ir deformacinių rodiklių vertès kitimas}

Apskritai statybinę keraminę medžiagą galima priskirti kvazitrapioms medžiagoms. Drégmè, esanti jos porose ir kapiliaruose, dar sumažina keraminés medžiagos trapumą. Keraminiam gaminiui sugeriant drègmę vyksta ir jo brinkimo procesas dèl skečiančiojo viršslègio pasireiškimo. Tai gali turèti didelès įtakos atsparumo šalčiui rodiklio vertèms. Vandenyje imirkyto šaldomo bandinio suirimas nèra staigus aktas. Kinetiniu aspektu prieš atsirandant pirmiesiems suirimo požymiams keraminio bandinio vidineje mikrostruktūroje vyksta žymūs pokyčiai. Defektų zonose vystosi itempimai ir didejja deformacijos. Keraminio gaminio linijinis deformavimas veikiant daugkartiniam vienpusiam šaldymui bei atšildymui sukelia medžiagos nuovargio ir liekamuju deformacijų sankaupas. Besikaupiančios liekamosios deformacijos charakterizuoja keraminio gaminio mikrostruktūros suirimo laipsni [1-3].

Charakteringu bandiniu pagrindiniai deformaciniai rodikliai pateikti 1 lentelèje. Paprastai išryškèja bendra tendencija, kad kuo didesnès teigiamos deformaciniu rodikliụ reikšmès, tuo mažiau tokie bandiniai atlaiko vienpusio šaldymo ir šildymo ciklu $\left(M_{1}, M_{2}\right)$. Pavyzdžiui, 2-asis bandinys nuo pirmuju suirimo požymių iki visiš- 
1 lentelè. Charakteringų keraminių gaminių pagrindiniai deformaciniai ir atsparumo šalčiui rodikliai

Table 1. Main deformation and frost resistance parameters of typical ceramic samples

\begin{tabular}{|c|c|c|c|c|c|c|c|}
\hline $\begin{array}{c}\text { Bandinio } \\
\text { šifras }\end{array}$ & $\Delta h_{1} / \Delta h_{11}, \mu \mathrm{m}$ & $\Delta h_{2} / \Delta h_{21}, \mu \mathrm{m}$ & $\Delta h_{3} / \Delta h_{31}, \mu \mathrm{m}$ & $s_{1} / s_{2}, \mathrm{~cm}^{2}$ & $s_{3} / s_{4}, \mathrm{~cm}^{2}$ & $M_{\mathrm{L}}$, ciklai & $M_{2}$, ciklai \\
\hline 1 & $13,8 / 3,5$ & $18,0 / 4,0$ & $21,0 / 5,0$ & $70,81 / 13,28$ & $93,15 / 17,45$ & 40 & 68 \\
\hline 2 & $11,4 / 1,8$ & $15,60 / 3,0$ & $16,20 / 4,8$ & $46,63 / 7,77$ & $63,21 / 13,26$ & 56 & 84 \\
\hline 3 & $6,3 / 2,4$ & $9,3 / 2,4$ & $11,1 / 6,9$ & $38,46 / 12,81$ & $42,49 / 24,27$ & 86 & 167 \\
\hline 4 & $6,0 / 2,5$ & $13,8 / 6,3$ & $17,7 / 8,4$ & $34,14 / 8,87$ & $75,23 / 24,45$ & 149 & 388 \\
\hline 5 & $1,2 / 0,3$ & $4,2 / 1,5$ & $4,8 / 1,8$ & $5,04 / 1,10$ & $24,38 / 8,0$ & 152 & 252 \\
\hline 6 & $0,6 / 0,3$ & $2,1 / 2,1$ & $3,3 / 3,0$ & $3,89 / 1,53$ & $12,4 / 7,89$ & 130 & 330 \\
\hline 7 & $1,0 / 1,0$ & $1,2 / 1,1$ & $1,5 / 1,4$ & $3,48 / 2,22$ & $4,83 / 2,90$ & 390 & 680 \\
\hline 8 & $-1,8 /-2,0$ & $-1,8 /-2,2$ & $-2,4 /-3,0$ & $-6,18 /-10,49$ & $-7,76 /-8,04$ & 155 & 266 \\
\hline 9 & $-1,5 /-0,60$ & $-3,0 /-2,9$ & $-3,9 /-3,1$ & $-6,20 /-3,65$ & $-20,70 /-16,66$ & 271 & 500 \\
\hline 10 & $-2,1 /-1,2$ & $-1,8 /-1,6$ & $-2,1 /-1,8$ & $-8,7 /-4,8$ & $-7,32 /-7,20$ & 229 & 398 \\
\hline 11 & $-0,6 /-1,2$ & $-1,2 /-1,8$ & $-1,5 /-2,1$ & $-3,06 /-4,73$ & $-4,63 /-8,1$ & 201 & 327 \\
\hline
\end{tabular}

ko šaldomojo paviršiaus suirimo dar atlaikẻ 28 vienpusio šaldymo ciklus ( 1 lent.). 7-asis bandinys, kurio deformacinių rodiklių reikšmès teigiamos, tačiau mažos, ne tik išlaikè daugiau ciklų iki suirimo pradžios, jam visiškai suirti reikejjo daugiau laiko, tai yra 290 ciklų.

Tai galima paaiškinti tuo, kad keraminių bandinių irimo procesas yra sudettingas ir labai susijęs su struktūros nevienalytiškumu $[2,3]$. Gaminiai, kurių defektai ir struktūros netolygumai koncentruojasi tiriamajame paviršiuje ir jų yra daug, suyra gana greitai. Kai defektų paviršiaus sluoksnyje yra nedaug, irimo procesas prasideda vèliau ir vyksta ilgiau, tokie bandiniai išlaiko daugiau ciklų.

Kaip matyti iš 1 lentelès, kitais atvejais deformacinių rodiklių reikšmès yra neigiamos (1 lentelès 8-11 bandiniai). Tokių bandinių, kurių deformacinių rodikliu reikšmès yra neigiamos, buvo mažiau negu bandinių, kurių deformacinių rodiklių reikšmès teigiamos. Vyrauja tendencija, kad kuo didesnès neigiamos deformacinių rodikliụ vertès, tuo toks keraminis gaminys atsparesnis šalčiui. Pavyzdžiui, gana dideliu atsparumu šalčiui pasižymi 9-asis bandinys, turintis neigiamas deformaciniu rodiklių reikšmes, - visiškai suiro po 500 ciklų (1 lent.).

Skirtingo ženklo deformacinių rodiklių vertes galima paaiškinti tuo, kad keraminių gaminių makro- ir mik- rostruktūros skiriasi, ir nevienodai vyksta vandens migracijos ir faziniu virsmy procesai.

Kai fiksuojamos deformacinių rodiklių vertès yra teigiamos ir didelès, tada, matyt, dominuoja vandens migracija ir kaupimasis bei vandens virsmas i ledą paviršinių sluoksnių defektų zonose arba didesnése pavojingose porose. Jose susidaręs ledas sukelia lokalinius itempimus, kurie pradeda ardyti keraminio gaminio paviršiaus sluoksnio mikrostruktūrą, atsirandant lokalinèms linijinèms deformacijoms. Kai šaldant atsiradę vidiniai struktūros pokyčiai yra negrižtami, išryškèja žymios liekamosios deformacijos. Cikliškai šaldant ir atšildant liekamosios deformacijos kaupiasi, kol viršijama stiprio riba ir tuomet gana greit prasideda keraminio bandinio paviršiaus irimas - išryškèja būdingi irimo požymiai (sluoksniavimasis, ištrupejjimas, aižèjimas).

Kai deformacinių rodiklių neigiamos vertès didelès, vyksta priešingi procesai. Vanduo ciklinio poveikio metu palaipsniui pašalinamas iš pavojingos paviršiaus zonos vykstant migracijos, garavimo, desorbcijos ir sublimacijos procesams. Tuomet keraminèse pusplytèse ir fiksuojame neigiamas linijines deformacijas ( 1 lentelès 8 ir 11 bandiniai). Tokiais atvejais vanduo, likęs paviršinio sluoksnio porose ir kapiliaruose, turi pakankamai vietos šaldomas plèstis, todèl nesukelia įtempimų keraminiame bandinyje, o bandinio deformacijos tampa neigiamos. 
Tai, kad gaminiai mūre, iskaitant keramines plytas, gali trauktis, yra žinoma [7]. Bet neabejotina, kad toks efektas vienpusio ciklinio šaldymo ir atšildymo atvejais yra nustatytas pirmą kartą. Tačiau šis procesas, būdingas dilatometrinių tyrimu atveju, iš dalies pasireiškia ir tiesioginių standartinių atsparumo šalčiui bandymų metu.

Procesus, vykstančius keraminiame bandinyje, galime bandyti paaiškinti ir energetiniu požiūriu.

Fiksuojamas sąlyginių deformacinių rodiklių $\left(s_{1}, s_{2}\right.$, $s_{3}, s_{4}$ ) teigiamas vertes galime bandyti paaiškinti kaip išsiskiriančią energiją, kuri yra sunaudojama vandens migracijai, sankaupoms bei ledo lęšių susidarymui defektų zonose ir keraminès medžiagos paviršiaus sluoksnio destrukcijai.

Kai sąlyginių deformacinių rodiklių vertès neigiamos, mūsu manymu, sugeriama energija yra naudojama tam, kad išsklaidytų drègmę iš keraminès medžiagos defektų zonų ir desorbuotụ vandeni iš jos porų ir kapiliarų, todèl energijos, kuri sukeltų sluoksnio suirima, nebelieka.

Atliekant tiesioginius keraminiu pusplyčių bandymus vienpusio šaldymo ir atšildymo būdu galimybè pasireikšti neigiamoms deformacijoms yra ribota, todèl, kad paviršiniai sluoksniai cikliškai pasipildo vandeniu lietinant bandinių paviršių atšildymo metu. Tačiau ir šiais atvejais yra daug didesni tokių keraminių bandinių atsparumo šalčiui rodikliai bei gerokai ilgesnè viso vienpusiai šaldomo paviršiaus suirimo eiga, kadangi ir tada paviršiaus sluoksniuose pasireiškia poru ir kapiliarų vandens išsklaidymas.

\subsection{Struktūrinių ir deformacinių rodiklių naudoji- mas keraminių gaminių sparčiajai atsparumo šalčiui prognozei}

Keraminèje šukèje susidarančiu itempimu dydžiui užšąlant joje vandeniui țtakos turi keraminio gaminio vandens imirkis. Todèl vienas iš svarbiausių rodiklių, naudotu kuriant spartuji metoda, - pasirinktas vandens imirkio rodiklis $W_{48}$. Tas rodiklis yra tiesiai proporcingas efektyvių poru kiekiui keraminèje šukèje. Mūsų atveju visi bandiniai patenka i sriti, kur poringumas neviršija 26\% (pagal tūri) [2], nes tiriamujų bandinių vandens imirkio rodiklio vertès kito nuo 2,27 iki $10,99 \%$.

Ištirtu bandinių atsparumo šalčiui rodikliụ priklausomybé nuo vandens imirkio pateikta 2 ir 3 paveiks-

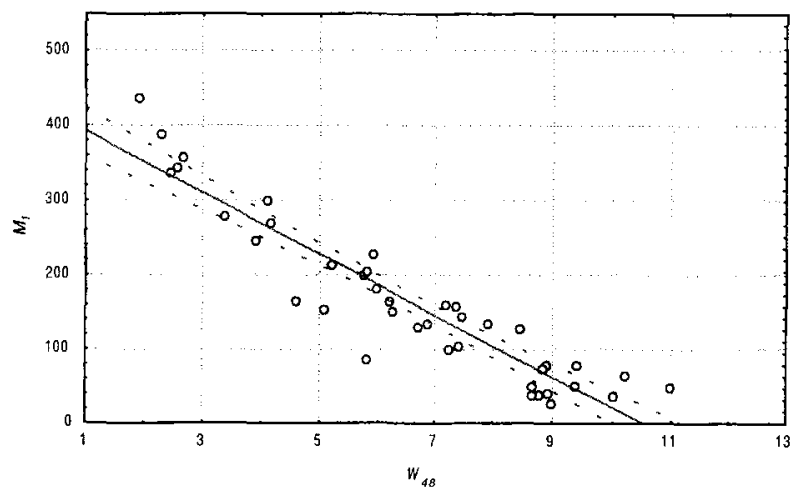

2 pav. Atsparumo šalčiui rodiklio priklausomybè nuo vandens ¿̇mirkio. Tiesinés regresijos lygis $M_{1}=434,83-41,29 W_{48}$

Fig 2. Relationship between frost resistance and water saturation. Regression equation $M_{1}=434,83-41,29 W_{48}$

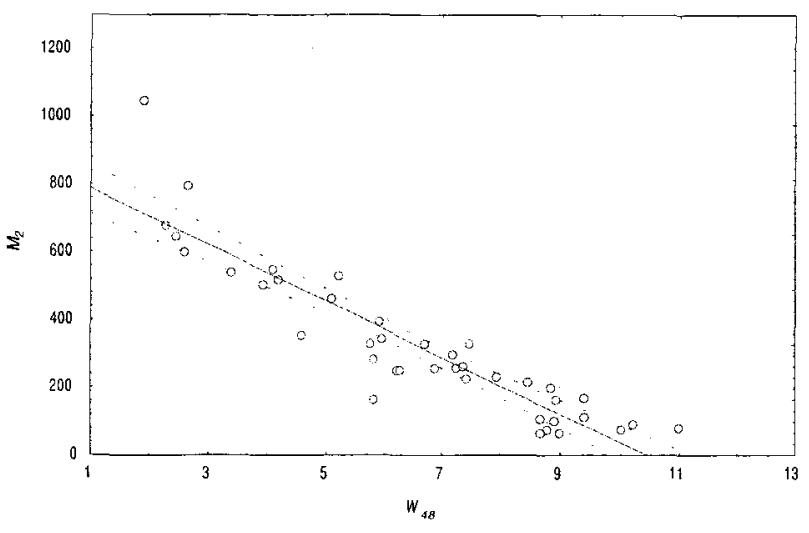

3 pav. Atsparumo šalčiui rodiklio priklausomybẻ nuo vandens imirkio. Tiesinés regresijos lygis $M_{2}=872,52-83,59 W_{48}$

Fig 3. Relationship between frost resistance and water saturation. Regression equation $M_{2}=872,52-83,59 W_{48}$

luose. Abiem atvejais išryškejja tokia bendra tendencija - kuo mažesnis gaminio įmirkio rodiklis, tuo jis atsparesnis šalčiui. Vandens imirkio rodiklis ypač gerai koreliuoja su atsparumo šalčiui rodikliais $M_{1}, M_{2}$, ir tai matome iš 2 ir 3 paveiksluose pateiktų duomenu. Tarp atsparumo šalčiui rodiklio $M_{1}$ ir vandens imirkio $W_{48}$ koreliacijos koeficientas $-0,9329$. Tarp atsparumo šalčiui rodiklio $M_{2}$ ir vandens imirkio rodiklio $W_{48}$ jis yra $-0,9143$. Šie rezultatai sutampa su žinomų tyrimų rezultatais [2]. Tačiau, kai efektyvus poringumas viršija $26 \%$, paprastai vandens imirkio rodiklis $W_{48}$ tampa tiesiogiai proporcingas eksploataciniam atsparumui šalčiui, kai dideja ir atvirų poru bei kapiliaru matmenys ir bendras poringumas $[2,3]$. 
2 lentelè. Keraminių bandinių deformacinių ir atsparumo šalčiui rodiklių koreliacijos koeficientų matrica

Table 2. Correlation coefficients matrix of deformational and frost resistance factors of ceramic specimens

\begin{tabular}{|c|c|c|c|c|c|c|c|c|c|c|c|c|}
\hline & $\Delta h_{1}$ & $\Delta h_{2}$ & $\Delta h_{3}$ & $\Delta h_{11}$ & $\Delta h_{2}$ & $\Delta h_{3}$ & $s_{1}$ & $s_{2}$ & $s_{3}$ & $s_{4}$ & $M_{1}$ & $M_{2}$ \\
\hline$\Delta h_{1}$ & 1,00 & 0,92 & 0,84 & 0,60 & 0,53 & 0,40 & 0,97 & 0,63 & 0,88 & 0,45 & $-0,68$ & $-0,69$ \\
\hline$\Delta h_{2}$ & - & 1,00 & 0,97 & 0,61 & 0,68 & 0,51 & 0,93 & 0,65 & 0,98 & 0,56 & $-0,69$ & $-0,69$ \\
\hline$\Delta h_{3}$ & - & - & 1,00 & 0,61 & 0,73 & 0,63 & 0,87 & 0,64 & 0,96 & 0,61 & $-0,65$ & $-0,66$ \\
\hline$\Delta h_{11}$ & - & - & - & 1,00 & 0,84 & 0,74 & 0,69 & 0,96 & 0,63 & 0,86 & $-0,36$ & $-0,42$ \\
\hline$\Delta h_{y}$ & - & - & - & - & 1,00 & 0,84 & 0,61 & 0,85 & 0,69 & 0,89 & $-0,44$ & $-0,50$ \\
\hline$\Delta h_{31}$ & - & - & - & - & - & 1,00 & 0,48 & 0,74 & 0,50 & 0,81 & $-0,37$ & $-0,44$ \\
\hline$s_{1}$ & - & - & - & - & - & - & 1,00 & 0,72 & 0,92 & 0,52 & $-0,66$ & $-0,67$ \\
\hline$s_{2}$ & - & - & - & - & - & - & - & 1,00 & 0,67 & 0,87 & $-0,43$ & $-0,51$ \\
\hline$s_{3}$ & - & - & - & - & - & - & - & - & 1,00 & 0,58 & $-0,68$ & $-0,68$ \\
\hline$s_{4}$ & - & - & - & - & - & - & - & - & - & 1,00 & $-0,30$ & $-0,39$ \\
\hline$M_{1}$ & - & - & - & - & - & - & - & - & - & - & 1,00 & 0,96 \\
\hline$M_{2}$ & - & - & - & - & - & - & - & - & - & - & - & 1,00 \\
\hline
\end{tabular}

Deformacinių ir atsparumo šalčiui rodiklių tarpusavio sąryšio duomenys pateikti 2 lentelèje. Iš 2 lentelés matyti, kad dauguma deformacinių rodikliu stipriai koreliuoja tarpusavyje. Gerais koreliaciniais ryšiais su atsparumo šalčiui rodikliu pasižymi absoliutieji deformaciniai rodikliai. Pavyzdžiui, $\Delta h_{2}$ koreliacijos koeficientai su $M_{1}$ ir $M_{2}$ atitinkamai yra $-0,69$. Sąlyginiai deformaciniai rodikliai $s_{1}$ ir $s_{3}$, kurie išreiškiami plotais, taip pat stipriai koreliuoja su atsparumo šalčiui rodikliais. Kaip matome iš 2 lentelès, koreliacijos koeficientai deformacinio rodiklio $s_{1}$ su atsparumo šalčiui rodikliu $M_{1}$ yra $-0,66$, o su $M_{2}$ atitinkamai $-0,67$. Ši preliminari analizè ( 2 ir 3 pav. bei 2 lent.) parodè, kad panašių savybių keraminiu plytu aibès eksploatacini atsparumą šalčiui $\left(M_{1}\right.$ ir $\left.M_{2}\right)$ būtų galima prognozuoti naudojant vandens imirkio bei absoliučiuosius ir sąlyginius deformacinius rodiklius. Toliau buvo svarbu nustatyti optimalias prognozavimo lygtis.

Atlikus gautų tyrimų rezultatų regresinę analizę išvestos formulès, kurios leidžia prognozuoti keraminiu gaminiu suirimo pradžią ir pabaigą (3 lent.) pagal empirines lygtis. Kaip matyti iš 3 lentelès, prognozuoti keraminių gaminių atsparumą šalčiui galima naudojant tiek vienos, tiek kitos grupès deformacinius rodiklius, taip pat ir vandens imirkio rodiklį.
(1), (3), (5), (7) lygtys yra skirtos prognozuoti keraminių gaminių atsparumą šalčiui pagal suirimo pradžią, o (2), (4), (6), (8) formulès - atitinkamai pagal suirimo pabaiga.

Tikėtina, kad ((1), (2) lygtys, 3 lent.) tinka prognozuoti keraminių plytų eksploatacinị atsparumą šalčiui, $o$, atsižvelgiant i empirinių lygčiu daugiamačio koreliacijos koeficiento ir dispersijos faktinius dydžius, tai prognozuoti galima gana tiksliai, tačiau paklaidos tikimybè yra didesné, kai naudosime tik absoliučiuosius deformacinius rodiklius. Tuo tarpu naudojant vien sąlyginius deformacinius rodiklius ((3), (4) lygtys, 3 lent.) prognozès tikslumo tikimybè mažesnè, o galimos paklaidos tam tikrais atvejais laukiamos mažesnès.

Kai jivertiname ir keraminiu gaminiu imirki $W_{48}$ bei deformacinius rodiklius, situacija keičiasi ((5-8) lygtys, 3 lent.). Tokiu atveju optimaliomis galima laikyti empirines lygtis, kuriose prognozuojant sienų keramikos gaminių atsparumą šalčiui naudojamas vandens imirkio rodiklis $\left(W_{48}\right)$ bei salyginiai deformaciniai rodikliai $\left(s_{1}\right.$, $\left.s_{2}, s_{3}, s_{4}\right)$. Šiuo atveju lygčių daugiamatès koreliacijos koeficientai yra didžiausi, o dispersijos mažai skiriasi, kai lygtyse naudojami absoliutieji deformaciniai rodikliai.

Taigi keraminių gaminių atsparumo šalčiui prog- 
3 lentelè. Keraminių plytų eksploatacinio atsparumo šalčiui prognozavimo empirinès lygtys

Table 3. Empirical equation for rapid frost resistance forecast of ceramic bricks

\begin{tabular}{|c|c|c|}
\hline $\begin{array}{c}\text { Lygties } \\
\text { Nr. }\end{array}$ & Empirinè lygtis & $\begin{array}{c}\text { Daugiamatės koreliacijos } \\
\text { koeficientas R, dispersija, } \\
\%\end{array}$ \\
\hline 1 & $\begin{array}{c}M_{1}=\exp \left(5,46507-0,09889 \Delta h_{1}-0,57520 \Delta h_{2}+0,026570 \Delta h_{3}+\right. \\
\left.0,267663 \Delta h_{1 l}-0,074504 \Delta h_{2 l}-0,05116 \Delta h_{3 l}\right)\end{array}$ & $\begin{array}{c}0,75808 \\
57,468\end{array}$ \\
\hline 2 & $\begin{array}{c}M_{2}=\exp \left(6,12117-0,11264 \Delta h_{1}-0,248520 \Delta h_{2}+0,028927 \Delta h_{3}+\right. \\
\left.0,247346 \Delta h_{1 l}-0,070875 \Delta h_{2}-0,05893 \Delta h_{3 l}\right)\end{array}$ & $\begin{array}{c}0,78271 \\
61,264\end{array}$ \\
\hline 3 & $M_{1}=\exp \left(5,42214-0,01448 s_{1}+0,011476 s_{2}-0,01818 s_{3}+0,013415 s_{4}\right)$ & 0,73388 \\
\hline 4 & $M_{2}=\exp \left(6,07272-0,01783 s_{1}+0,011315 s_{2}-0,01349 s_{3}+0,007576 s_{4}\right)$ & 53,858 \\
\hline 5 & $M_{1}=\exp \left(6,4314-0,2058 W_{48}-0,02443 \Delta h_{1}-0,01976 \Delta h_{3}+0,009608 \Delta h_{1 l}+\right.$ & 0,74148 \\
$\left.0,021045 \Delta h_{3}\right)$ & 54,979 \\
\hline 6 & $M_{2}=\exp \left(7,0834-0,2049 W_{48}-0,03275 \Delta h_{1}-0,01226 \Delta h_{3}-0,004258 \Delta h_{1 l}+\right.$ & 0,97175 \\
$\left.0,011584 \Delta h_{3 l}\right)$ & 94,431 \\
\hline 7 & $M_{1}=\exp \left(6,4001-0,1948 W_{48}-0,0096 s_{1}+0,018276 s_{2}-0,00449 s_{3}-\right.$ & 0,97321 \\
$\left.0,01009 s_{4}\right)$ & 94,714 \\
\hline 8 & $M_{2}=\exp \left(7,1319-0,2087 W_{48}-0,015956 s_{1}+0,02273 s_{2}+0,001297 s_{3}-\right.$ & 0,97521 \\
$\left.0,00715 s_{4}\right)$ & 95,104 \\
\hline
\end{tabular}

nozè naudojant $W_{48}$ rodiklius ir sąlyginius deformacinius rodiklius $s_{1}, s_{2}, s_{3}, s_{4}$ yra patikima ir gana tiksli. Be to, tokiu atveju atliekant tyrimus pakanka dvieju šaldymo ir atšildymo ciklụ, taip pagreitiname bandymus ir sumažiname darbo sąnaudas.

Visais atvejais išryškejja ta pati tendencija (3 lent.), jog didesni koreliacijos koeficientai gaunami prognozuojant bandinių suirimo pabaigą nei suirimo pradžią. Tai sutampa su ankstesnių tyrimų rezultatais [2].

Pasinaudojus išvestomis formulemis keraminių dirbinių atsparumą šalčiui galima nustatyti per gana trumpą laikotarpi (3-5 paras, îskaitant bandiniu išdžiovinimą iki pastovios masès).

\section{Išvados}

1. Skirtingos struktūros įmirkytų keraminių pusplyčių, jas vienpusiai šaldant ir atšildant, deformacinių rodiklių vertès kinta plačiu diapazonu.

Neigiamos absoliučiuju bei sąlyginiu deformaciniu rodiklių vertès vienpusio ciklinio šaldymo ir atšildymo metu eksperimentiškai fiksuotos pirmą kartą. Tokių keraminių gaminių eksploatacinis atsparumas šalčiui yra gana didelis.
2. Išvestos naujos empirinés eksploatacinio atsparumo šalčiui prognozavimo lygtys gana mažo poringumo keraminėms paprastoms ir apdailos plytoms. Optimaliai prognozuoti tokių gaminių charakteringo suirimo pradžią ir pabaigą ciklinio vienpusio šaldymo ir atšildymo atveju galima pagal vandens imirkio $\left(W_{48}\right)$ bei sąlyginius deformacinius $\left(s_{1}, s_{2}, s_{3}, s_{4}\right)$ rodiklius. Minimali prognozavimo trukmé tokiu atveju yra 3 paros.

\section{Literatūra}

1. А. С. Садунас, Р. В. Мачюлайтис, А. Ю. Каминскас. Проблема эксплуатационной морозостойкости кирпича и реальные пути её решения // Строительные материалы, 1984, № 9, с. 25-36.

2. Р. В. Мачюлайтис. Морозостойкость и долговечность изделий фасадной керамики. Вильнюс: Техника, 1997. $308 \mathrm{c}$.

3. A. Sadūnas. Aliumosilikatinių dirbinių ilgaamžiškumas. Vilnius: VPU leidykla, 1997. 252 p.

4. A. Kičaitė. Keraminiu gaminių atsparumo šalčiui sparčiujų prognozavimo metodu raida // Statyba, V t., Nr. 3. Vilnius: Technika, 1999, p. 222-228.

5. О. Д. Паращенко, К. А. Валешко, П. М. Гуденко, Д. Н. Квасницкая. Экспресс-метод определения морозостойкости керамических материалов. Реф. инф., серия "Промышленность стеновых материалов, 
пористых заполнителей и местных вяжущих". Вып. 3. М.: ВНИИЭСМ, 1975. 75 с.

6. А. Садунас, Р. Мачюлайтис, Д. Буре. Долговечность строительной керамики. Вильнюс: ЛитНИИНТИ, 1987. $36 \mathrm{c}$.

7. G. Marčiukaitis, J. Valivonis. Mūro susitraukimo deformaciju ivertinimas, analizuojant pastatu vidiniu sienu supleišejimą // Statyba, VI t., Nr. 1. Vilnius: Technika, 2000, p. $11-16$.

lteikta $2000 \quad 0825$

\section{NEW EQUATIONS FOR PREDICTING THE FROST RESISTANCE OF CERAMIC PRODUCTS BY DEFORMATIONAL PARAMETERS}

\section{A. Kičaitè, R. Mačiulaitis}

S u m mary

One of the important parameters describing durability is the resistance to frost. It can be determined by direct and rapid prediction methods. Investigations by direct methods last from some days to several months. Frost resistance of ceramic products can be estimated fast by rapid prediction methods.

One of important directions of the rapid prediction methods is the dilatometric method, which is sensitive to the changes of internal structure and related to tensions and deformation by freezing and thawing. One of dilatometric apparatus is DUM-01, which can establish many deformation parameters by one-sided freezing of ceramic bricks.

Clay bricks made by plastic extrusion and by semi-dry pressing were tested.

We have estimated what values of deformative parameters of ceramic bricks change in a wide range from negative to positive. The bigger the positive values of deformation parameters, the less number of ceramic samples is resistant to frost.

We think that the observed negative values of deformation parameters appear because of water migration in ceramic bricks from defective zones. The ice formed in large pores does not destroy ceramic products and they have possibility to shrink.

It was established that objective forecast for the frost resistance of ceramic bricks must be carried out using water absorption and two groups of deformation parameters.

Prediction methods according to structural and deformational properties have been developed. Testing by these methods lasts 3 days.

Rapid prediction methods for frost resistance of ceramics products are more convenient and prospective due to structural and deformational properties.

Asta KIČAITÉ. Doctor, Senior Assistant. Dept of Building Materials. Vilnius Gediminas Technical University, Sauletekio al. 11, LT-2040 Vilnius, Lithuania. E-mail: stsm@st.vtu.lt

Doctor (technical sciences, 1991). Author of 19 publications. Research interests: durability, frost resistance and other properties of building materials and products.

Romualdas MAČIULAITIS. Doctor Habil, Professor. Head of Dept of Building Materials. Vilnius Gediminas Technical University, Sauletekio al. 11, LT-2040 Vilnius, Lithuania. E-mail: romualdas.maciulaitis@st.vtu.lt

Doctor (technical sciences, 1980). Doctor Habil (technical sciences, 1993). Professor (1999). Author of 120 publications. Research interests: durability, frost resistance and other properties of building materials and products, fire protection and processes. 